\title{
Study on Innovation and Entrepreneurship Education in Chinese Universities and Colleges
}

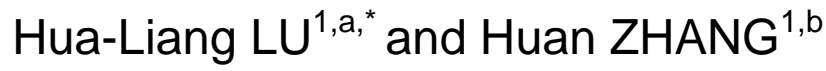 \\ ${ }^{1}$ School of Business Administration, Nanjing University of Finance \& Economics, Nanjing, China \\ a1416261621@qq.com, bzhanghuannc@163.com \\ ${ }^{*}$ Corresponding author
}

Keywords: Innovation and Entrepreneurship, Higher Education, Mode, Universities and Colleges

\begin{abstract}
Since the Ministry of Education implemented the reform of innovation and entrepreneurship education, Chinese universities and colleges have opened up a large number of innovation and entrepreneurship programs, participated in "Innovation and Entrepreneurship" program and established a number of "Innovation and Entrepreneurship" demonstration bases and achieved fruitful results. However, the problems such as the immature curriculum system of innovation and entrepreneurship education, weak teachers and the imperfect education mode still restrict the development of innovation and entrepreneurship education in China. This paper analyses the importance and problems of innovation and entrepreneurship education in China, and point out the routines and paths for further development of innovation and entrepreneurship education in China.
\end{abstract}

\section{Introduction}

In April 2017, at the forum on reform and innovation in higher education, Premier Li proposed that "innovation is the source of promoting national development and social progress. Higher education should focus on serving the country's innovation and development and cultivate more innovative talents to achieve the public entrepreneurship, the goal of innovation "[1]. The concept of innovation and entrepreneurship education emerged as the times require and matched with its own economic and social development and the progress of higher education. It is of strategic importance and educational value and has drawn wide attention from universities and academics. However, the history of innovation and entrepreneurship education in Chinese universities is very short, still at early development stage, and lack of systematic and practical effectiveness. There is a need to deep explore the key issues in the process of innovation and entrepreneurship education. Innovation and entrepreneurship education in Chinese universities has become the important part of Chinese higher education. The Ministry of Education attaches great importance to promoting innovation and entrepreneurship education in universities and promoting the independent entrepreneurship of university students, which requires us to conduct a comprehensive analysis and explore the current situation of innovation and entrepreneurship education, and point out the path for future development of innovation and entrepreneurship education in Chinese universities [2].

\section{The Necessity of Carrying Out Innovation and Entrepreneurship Education in Chinese Universities and Colleges}

First of all, Carrying out innovation and entrepreneurship education is to adapt the trend of economic and social development in China. Into the global knowledge economy era, talent competition has gradually become the primary international competition. Talent becomes a key factor in implementing innovation-driven strategies. Present Xi pointed out: China must take the lead in science and technology innovation in the world. We must find talents in innovative practice, nurture talents in innovative activities, and pool talents in innovative undertakings. We must make great efforts to bring forth new ideas that are large-scale, well-structured and of good quality 
Science and technology personnel. At present, cultivating innovative talents has become a key measure to improve the capability of independent innovation. As the main force of talent output, universities have not yet reached the requirement of building an innovative nation. Therefore, only by vigorously promoting innovation and entrepreneurship education at higher education institutions and by cultivating more high-level talents with innovative entrepreneurship can we provide talent support for the realization of the national innovation system and eventually build an innovation-oriented nation[3].

Second, Carrying out innovation and entrepreneurship education is also adapted to the requirements of self-development of universities. It has become the most crucial and urgent task for higher education to step into the comprehensive education reform and improve the quality of qualified personnel. Nowadays, teaching in universities is still dominated by cramming and instilling teaching methods. Students conduct self-exploration and there is little room for discussion. Education should not be blindly instilled. The ultimate goal of education should be to stimulate the potential of each student, cultivate the desire of active learning, and stimulate the passion of innovation. Innovation and entrepreneurship education is the core of the reform of traditional personnel training mode, innovative teaching methods and content of education, and pay more attention to cultivate the individual's ability and quality rather than pure knowledge. In the teaching process, innovation and entrepreneurship education emphasizes the interaction between teachers and students, not only limited to teaching basic knowledge, but also focusing on the study into the classroom. Therefore, carrying out innovation and entrepreneurship education in universities and colleges is conducive to establishing a good career outlook for college students and realizing their own values to contribute to the socialist modernization. It is also conducive to cultivating the university students' awareness of serving the country and the people and innovating daringly to try Spirit and ability to solve practical problems; is conducive to promoting college students' learning initiative and entrepreneurship, cultivating their entrepreneurial passion, and improving the overall quality of college students [4]. Therefore, focusing on innovation and entrepreneurship education for universities and colleges to improve teaching quality, promote the development of education in China is very necessary.

\section{The Problems of Innovation and Entrepreneurship Education in Chinese Universities and Colleges}

In 1997, China carried out the undertaking of innovation and entrepreneurship education in various universities and colleges, and it has been more than 20 years since its establishment [5]. The basic disciplinary system has been basically completed and a large number of innovative talents have been trained for the socialist modernization in China. However, focusing on the long-term needs of the development of the party and state, the current education system and curriculum are not yet mature, teachers are weak, and teaching models are not perfect, which have constrained the country's demand for innovative talents.

First, innovation and entrepreneurship education system in universities is immature, and teaching methods are relatively simple. Some universities have not given enough attention to the innovation and entrepreneurship education curriculum construction, did not set up a wealth of courses related to innovation and entrepreneurship education, the teaching process does not use targeted teaching materials, only one-sided reference to college students career guidance class teaching materials, which Unable to achieve the fundamental purpose of innovation and entrepreneurship education. At the same time, some teaching methods for innovation and entrepreneurship education in universities and colleges are rather traditional and single, and "classroom teaching" occupies the main teaching time, and lacks practical training. The contents of the lecture are limited to the book knowledge. The "spoon-feeding" education may still be the main way of teaching, with less interaction with students, students 'ability to solve practical problems not being tempered, students' initiatives and innovations not being effectively cultivated [6]. 
Second, teachers for innovation and entrepreneurship education in Chinese universities and colleges are relatively weak. The innovation and entrepreneurship education in Chinese universities and colleges has a history of less than 10 years. The talent pool is not huge. There is still a big gap between the degree of specialization and the developed countries. The quantity of teachers and the quality of teachers have more deficiencies. First of all, from a quantitative point of view, due to the limited financial and material resources and other hard conditions, universities are not qualified or able to hire experts in this field to carry out innovation and entrepreneurship guidance for students. Some universities directly assign teachers in charge of student employment to teach, and some universities even employ professors related to innovation and entrepreneurship, such as management, economics and other professional teachers to carry out innovation and entrepreneurship education. This has led to the absence of a dedicated teaching and research team in universities and the fact that more schools adopt a one-to-many massively collective teaching method that cannot organize small groups of interactions or one-on-one coaching, which is also limited by the size of the faculty [7] .Second, the professionalism of teachers needs to be improved. On the one hand, the instructors are lack of systematic professional training, there is no comprehensive and systematic knowledge of their own reserves, professionalism is not high. On the other hand, teachers lack the necessary entrepreneurial experience. Most teachers do not have their own business experience, just limited to theoretical knowledge, lack of certain entrepreneurial skills, and when facing of practical problems, it is difficult for them to give students effective advice. In other words, the lack of innovation and entrepreneurship education teachers in universities, lack of professionalism and other conditions have constrained the development of China's innovation and entrepreneurship education.

Third, the education mode of innovation and entrepreneurship education in Chinese universities and colleges is not optimized. Some Chinese universities have not yet covered the content of innovation and entrepreneurship education for students, nor do they have a comprehensive and systematic training model for innovation and entrepreneurship. Students are only satisfied with graduating credits and more elective courses and lectures, Student club activities and other informal forms of education. At the same time, the proportion of credit hour and credit hour in innovation and entrepreneurship education is still low compared with other mature subjects, the degree of integration with other disciplines still needs to be improved, and the lack of a comprehensive and systematic education model supports [8].

\section{The Development Paths for Innovation and Entrepreneurship Education in Chinese Universities and Colleges}

\section{Optimizing the curriculum system of innovation and entrepreneurship education}

Optimizing the curriculum system is an important part of the follow-up further promotion of innovation and entrepreneurship education. Universities must take training objectives as a reference to gradually improve the breadth and depth of the curriculum. Abandon the traditional education system, to meet the individual needs of students as much as possible, to promote innovation and entrepreneurship education through public basic courses, professional compulsory courses, professional elective courses, practical training and other more flowers to give students as much select. At the same time, with the development of the times, universities should also actively explore, cooperate with each other and learn from each other. They should continue to explore educational modes that meet the complex needs of students and enrich the curriculum system of innovation and entrepreneurship education. For example, universities can join the innovation and entrepreneurship education in the form of compulsory courses in student development programs, increase course credits and cross-integrate with other disciplines in order to enhance students' attention and interest. Some universities in the process of teaching more emphasis on the practical ability to solve the problem, the use of online courses and other means of education, such as the development of "business finance management" "business opportunities and business plan" and 
other professional elective courses, integration of various types of high quality resources to explore suitable for this school Students innovation and entrepreneurship education curriculum system, enabling students to further improve the ability of innovation and entrepreneurship.

\section{Building innovation and entrepreneurship education models to meet the needs of the self-development of universities and colleges}

On the one hand, in carrying out the innovation and entrepreneurship education in universities and colleges, we must cultivate a set of education models that are in line with the actual situation in light of the universities' concept of running a university and the socio-economic conditions of the region. For example, actively organize students to participate in competitions such as the "Challenge Cup" college students' entrepreneurship programs in China, combine theoretical knowledge with practice, and gain growth through exchanges with entrepreneurship supervisors; meanwhile, they should also be good at integrating resources both inside and outside universities, In cooperation with enterprises and institutions, we set up an off-campus innovation and entrepreneurship training base so that students have more practical opportunities to improve their innovative spirit, entrepreneurial quality and ability in the course of project research [9].

On the other hand, it serves as a bridge between students and businesses, building bridges for students and creating internships. The business practice platform for internship observation enables students to gain a close understanding of the business and actually experience the specific work of the business. Students to business internships, the state of the business can have a more in-depth understanding, and then the actual problems that can arise back to the classroom. Chinese universities should establish cooperation with multiple parties to establish a high quality and professional internship platform for students so as to enhance their enthusiasm for carrying out actual combat exercises to enterprises. Schools and enterprises should cooperate fully, in addition to co-operation with the establishment of a number of internship centers, making enterprises more willing and convenient to absorb college students internship, for some owned enterprises universities, to encourage them to often carry out business activities, The purpose is to create a good environment for students internships and training and entrepreneurship education, to provide more internship opportunities. Relevant laws and regulations as well as the introduction of the policy system can also encourage enterprises to provide high quality and suitable school enrollment and internship positions to promote the establishment of internship practice platform. Correspondingly, the government should provide the necessary financial support and preferential policies for the enterprises.

\section{Strengthen the construction of teachers of innovation and entrepreneurship education}

Innovation and entrepreneurship education in colleges not only requires professional, but also full-time teachers and relatively stable part-time teachers, the full-time teachers, part-time teachers, supplemented by the most reasonable form of teaching, so as to create a mutually reinforcing and optimal allocation of innovation and entrepreneurship teaching faculty.

First, setting up professional full-time teachers. Full-time teachers need to have a solid theoretical foundation and rich experience, combined with professional and industry differences to set up excellent teaching team, pay attention to the teaching of high quality and advance with the times. In addition, the contingent of full-time teachers needs to be stable and therefore necessary for team building. As a result, these full-time teachers have a relatively bright career prospect and can control the phenomenon of brain drain to a certain extent, thereby increasing the team's stability. Full-time teachers need constant training to improve their teaching. In addition to theoretical knowledge, practical training of full-time teachers should be carried out on a regular basis to enhance their practical teaching ability and to encourage full-time teachers to gain experience in entering social practice.

Second, establishing stable part-time teachers. Innovation and entrepreneurship education not only needs to guide students' theoretical knowledge, but also to cultivate their execution ability and 
putting the entrepreneurial intention into action through theoretical knowledge. Therefore, innovation and entrepreneurship teachers need not only have horizontal comprehensive ability, but also have some vertical professional ability. Innovation and entrepreneurship education covers subjects such as economics, management, accounting and law, and strives to comprehensively and systematically help students to consolidate students' theoretical knowledge. Therefore, universities and colleges should invite entrepreneurs, scientists and practitioners to work as part-time teachers, to hold regular lectures or exchange meetings, and even to set up courses to show students practical problems that may arise during start-up process.

\section{Improving the evaluation system of innovation and entrepreneurship education}

A good evaluation system is the key to the smooth running of any work. Innovation and entrepreneurship education is no exception. During the supervision and evaluation of all aspects of innovation and entrepreneurship education, problems can be found in a timely and accurate manner and suggestions can be put forward in a targeted manner Can effectively feedback and form a circular circulation system. Universities can start from the teaching concept and training objectives, formulate the corresponding long-term evaluation and short-term evaluation, subjective evaluation and objective evaluation of evaluation criteria.

Effective evaluation system can be related to the following aspects: First, the evaluation of innovation and entrepreneurship education system, the evaluation content should include both the arrangements for the university students' curriculum system, but also to cover the operation of the practice system. On the curriculum system curriculum, curriculum materials, teaching mode, assessment content, comprehensive organization to participate in the national college students business plan competition, entrepreneurial community and other practical activities, a comprehensive assessment of innovation and entrepreneurship education in universities and colleges. Secondly, the evaluation of the results of talent cultivation includes the awards of participating in various types of entrepreneurship competitions, the entrepreneurial intention after graduation, the entrepreneurial skills and the success rate of entrepreneurship, and examines whether the curriculum content of universities and colleges can really translate into practical achievements. Finally, the evaluation of industries related to innovation and entrepreneurship includes the operation of innovative entrepreneurship incubators, industrial parks and laboratories, and the assessment of the actual economic and social benefits of the organizations or units [10].

\section{Acknowledgement}

Authors are grateful to the financial support from Natural Science Foundation of China (71773046), Jiangsu Social Science Foundation (16HQ014), Higher Education Philosophy and Social Science Research Fund of Education Department of Jiangsu Province (2017ZDIXM061), The Higher Education Reform Research Project of Jiangsu Province (2015JSJG035) The 13th 5-year Key Project of Jiangsu Education Science (B-b/2016/01/23), Qing Lan Project of Higher Education of Jiangsu Province and Six Talent Peak Project of Jiangsu Province.

\section{References}

[1] General Office of the State Council, The implementation of deepening innovation and entrepreneurship education in universities and colleges, 2015-05-13.

[2] Y. Zhang, The conceptual and strategic thinking of innovation and entrepreneurship education in universities and colleges. China Higher Education, 23 (2010) 45-46.

[3] S. Wang, The study on the development strategy of innovation and entrepreneurship education in universities and colleges, China Audit Education, 10 (2016) 76-78. 
[4] Z. Li, My opinion on innovation and entrepreneurship education, China University Teaching, 4 (2014) 5-7.

[5] S. Zhang, Carrying out ideological and political work throughout the whole education process and opening up the new situation in the development of higher education in China, People News, 2016-12-09.

[6] D. Liu, Problems and development ideas of innovation and entrepreneurship education in universities and colleges, Education Review, 11 (2017) 88-91.

[7] L. Yan, B. Qu, The key problems and realistic countermeasures of innovation and entrepreneurship education in universities and colleges, Education and Vocation, 22 (2017) 62-67.

[8] J. Zhong, The present situation and innovation model of innovation and entrepreneurship education in universities and colleges, Continue Education Research, 8 (2016) 7-9.

[9] W. Li, C. Li, X. DU, Chinese universities and colleges start up education. The decade of innovation and entrepreneurship education in universities and colleges: evolution, problem and system construction. Educational Research, 6 (2013) 42-51.

[10] Z. Wang, Z. Liu, H. Liu, The status, problems and trends of innovation and entrepreneurship education evaluation. Ideological \& Theoretical Education, 8 (2016) 89-94. 